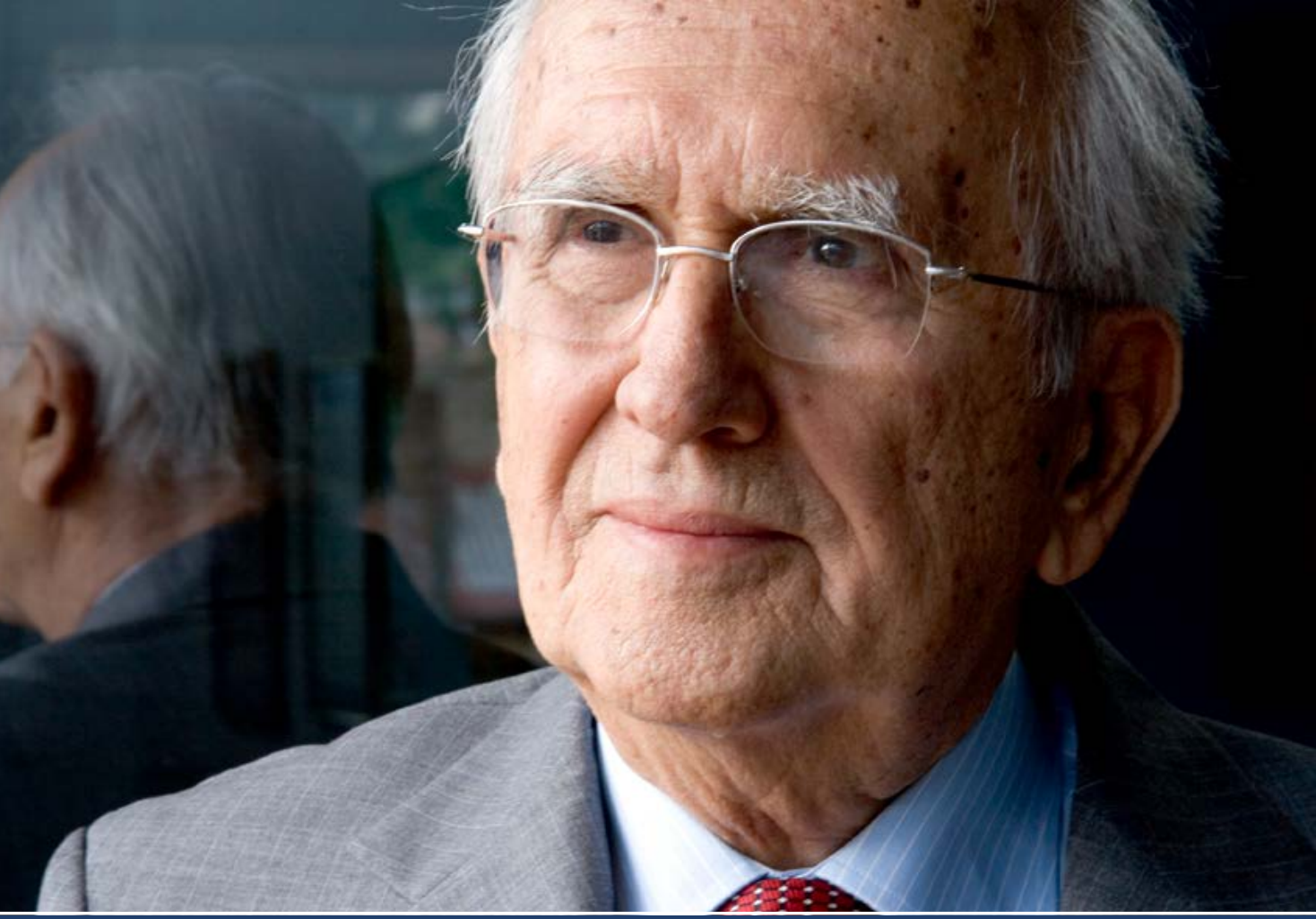

\title{
Politički život bosanskohercegovačke protukomunističke emigracije
}

Prof. dr. Šaćir Filandra

89-95.

Adil Zulfikarpašić i liberalne političke inicijative ZBORNIK RADOVA 



\title{
Politički život bosanskohercegovačke protukomunističke emigracije
}

\author{
Prof. dr. Šaćir Filandra \\ Fakultet političkih nauka Univerziteta u Sarajevu \\ filandra@hotmail.com
}

SAŽETAK: Adil Zulfikarpašić je najznačajnija ličnost bosanskohercegovačke protukomunističke emigracije. Emigrantski politički život je posvetio demokratizaciji i liberalizaciji rodne zemlje, a u skladu s najuzvišenijim principima humanizma i slobode. Na tim principima je aktivno sudjelovao u svim institucionalnim oblicima okupljanja jugoslavenske emigracije na Zapadu. Liberalizam i antifašizam su osnovne idejne vodilje njegovog političkog angažmana.

KLJUČNE RIJEČı: antifašizam, liberalizam, bošnjaštvo, Bosna, demokratija

Adil Zulfikarpašić je bio metafora Bosne. Bogatim i dugim životom u svojoj ličnosti je spajao njene različite likove: onaj starojugoslavenski između dva svjetska rata, komunistički/antikomunistički iz epohe socijalizma te liberalnodemokratski nakon pada socijalizma. No, još ima pojedinaca dugog trajanja u Bosni, pa ni približno nisu interesantni niti za nju značajni kao Zulfikarpašić. Ono što njega izdvaja, i to znatno u odnosu na savremenike, nije samo strast i ljubav prema Bosni, svojoj zemlji i državi, već znanje o njoj, kao i shvatanje značaja produbljivanja, održavanja i širenja toga znanja za oblikovanje svijesti njenih ljudi. Povodom desetogodišnjice njegove smrti naglasit ću samo pojedine odlike njegovog mišljenja i djela.

Prvo, Zulfikarpašić je strasno volio Bosnu. Kao da je njenu vrijednost, osobnost i veličinu bolje od nas domaćih uviđao s pozicije emigrantskog statusa. U toj izvandomovinskoj poziciji njegov nacionalni i kulturnoidentitetarni dignitet bio je jako izražen. Onkraj integrirajuće jugoslavenske ideologije, koja je dobrim dijelom u pojedinim fazama Bosnu svodila na samo geografski pojam, on je baštinio i sve vrijeme isticao bosanski zemaljski, kulturni, tradicijski i državni identitet i kontinuitet.

Mada je u političkom smislu neposredno nakon emigriranja djelovao u krugovima hrvatske inteligencije, on je prvom prilikom, a to se desilo na- 
kon javnog predočavanja činjenica o pokušajima katoličkog prozelitizma prema bosanskomuslimanskim emigrantima, istupio s nedvosmislenih bošnjačkih pozicija. Naime, određeni hrvatski katolički krugovi u emigraciji „prodavali” su karte, dokumente i slobodu bošnjačkim emigrantima na njihovom putu za Ameriku pod uvjetom prihvatanja katoličanstva. Zulfikarpašić se otvoreno tome usprotivio. Njegov protest protiv takve prakse ranih pedesetih godina desio se iz nužnosti odbrane osnovnih ljudskih, vjerskih i nacionalnih prava Bošnjaka. Kada se analizira taj protest i istup Zulfikarpašića i njegove grupe istomišljenika, mora se priznati da je to stavilo Bošnjake u centar političkih događanja u cijeloj emigraciji, a naročito hrvatskoj. Osim toga, to se pokazalo kao samostalno i autentično bošnjačko istupanje, bez ikakvih utjecaja, konsultiranja ili znanja vodećih političkih faktora hrvatske ili neke druge političke stranke i pokreta. Protest je bio pametan, energičan i utemeljen akt koji je pokazao da su bošnjački javni radnici u emigraciji pedesetih godina XX stoljeća politički svjesni, nacionalno drugačiji i posebni te da su njihovi interesi i dalja borba mogući jedino pod vodstvom vlastitih prvaka, kao i da su ti prvaci izvorno političari koji vladaju vještinom artikuliranja vlastitih interesa. Ovaj protest je najavio rađanje jedne samostalne bošnjačke grupe i bilo je samo pitanje dana kada će se ona i u institucionalnom smislu ograditi od srpskih i hrvatskih programa i istupiti u okviru vlastitog nacionalnog cilja.

Strast, pretpostavku i izvorište svakog velikog djela po Hegelu Zulfikarpašić je pretočio u Bošnjački institut i njegovu vrijednu knjišku zbirku. Mogao je on novce koje je s vremenom stekao i na drugi način potrošiti, mogao se predati hedonizmu, ali nije; imao sam prilike s njim tražiti i kupovati knjige o Bosni po Švicarskoj i tu njegovu strast za znanjem sam posvjedočio. Bio je poslovan čovjek, ali prije svega intelektualac. Znao je mjesto i funkciju znanja i kulture u savremenom svijetu. On je znao, iz evropske perspektive, da se jedna nacija, kao i država, prije svega mora kulturno legitimirati i predstavljati, kultura je tijelo nacije, i male nacije mogu imati velike kulturne domete.

Zulfikarpašiću su bogumili bili tajna i ključ Bosne. Bosanska crkva, bosanski krstjani ili bogumili, zavisno od toga kako se imenuje taj duhovni pokret u srednjovjekovnoj Bosni, bili su njegova velika tema, velika strast, misterija kojom se najistrajnije bavio. U bogumilima, naziv koji je on najčešće koristio, vidio je osobnost bosanskog duha, društvenog, kulturnog i političkog individualiteta te zemlje i njenog naroda. Bio je odličan poznavalac heterodoksnih pokreta rane srednjovjekovne Evrope, često je pričao o katarima, posjećivao mjesta njihova stradanja u Francuskoj i dovodio ih u vezu s bosanskim hereticima. 
Njegovu koncepciju Bosne i bošnjaštva nije moguće razumijevati bez stavova o bogumilstvu. Povezujući religiju, teritoriju i državu, Zulfikarpašić je uvijek isticao da Bosna posjeduje karakteristične uvjete koji je legitimiraju kao državu i snažnu posebnost. „Ona je jedna od rijetkih zemalja koje u procesu svoga stvaranja u srednjem vijeku imaju svoju teritoriju, svoju vjeru - bogumilsku, koja potječe iz manihejsko-dualističkog korijena kao što kršćanstvo potječe iz židovskoga, i na tom teritoriju stvara državu." "Zulfikarpašić vjeru srednjovjekovnih bosanskih ljudi, Bošnjana, nije smatrao nikakvom sektom ili herezom katoličkom, već posebnom, autentičnom religijom s vlastitim teološkim kredom i specifičnom organizacijom i strukturom na jednom, bosanskome prostoru. U svojoj koncepciji bogumilstva smatrao je da su oni u svom teološkom fundusu posjedovali elemente koji su ih činili predislamskim učenjem, učenjem bliskim islamu, odnosno da je bogumilstvo kao takvo bilo osnovni razlog zašto je bošnjačko stanovništvo tako masovno prihvatilo islam.

Drugo, Zulfikarpašić je iznad svega cijenio vrijednosti mira. Cjelovitost Bosne, bošnjaštvo, demokratija i islam bile su kategorije i vrijednosti unutar kojih se odvijala njegova politička djelatnost. On je iz zemlje otišao iz demokratskih pobuda i sve vrijeme je pripadao demokratskoj emigraciji. Kako nije bio komunista po uvjerenju, iako je pripadao NOP-u tokom Drugog svjetskog rata, nikada nije postao antikomunista ni po uvjerenju ni po zanimanju, kakvih je mnogo slučajeva u emigraciji bilo. On je od početka pripadao demokratskoj emigraciji okupljenoj oko Šubašića, Gažija, Krnjevića i dr. Kao predstavnik Bošnjaka, skupa s Teufikom Velagićem, sudjelovao je u osnivanju Demokratske alternative 1963. godine, udruženja demokratske jugoslavenske emigracije, u Stanstedu kod Londona. To se udruženje zalagalo za demokratsko preuređenje Jugoslavije na principima narodnog samoopredjeljenja i ravnopravnosti naroda, a u konfederalnoj državnoj formi, zajednici suverenih država koja bi imala zajedničku monetarnu i vanjsku politiku. Dok se Jugoslavija, i prva i druga, sve vrijeme politički „lomila” i dijelila na unitariste i federaliste, Demokratska alternativa je, svjesna nužnosti raspada zemlje, a što nama tih godina nije bilo ni u najlošijoj primisli, tražila modalitet njenog opstanka izvan koncepata federalizma i unitarizma, koje je smatrala nerealnim/neodrživim. Mir i političko rješenje nacionalnih sporova, a što nam se devedesetih nije desilo, on je zagovarao iznad svega. Znao je da mali stradaju u sukobima većih i velikih. Na njegovu ličnost veliki je dojam ostavilo stradanje Bošnjaka od četnika 1942. godine u rodnoj Foči i ta memorija je snažno utjecala na njegov spisateljski i politički rad.

Okovana Bosna, razgovor Adila Zulfikarpašića, Vlade Gotovca, Mike Tripala i Ive Banca, drugo izd., Bošnjački institut, Zürich, 1995, str. 19. 
To što je demokratska jugoslavenska emigracija priznala postojanje Bošnjaka kao ravnopravnog političkog činioca jugoslavenske nacionalne i državne zajednice ogroman je pomak $u$ razvoju političkih stavova te emigracije. Za razliku od Stanstedskog nacrta, kako se uobičajeno zvao prijedlog Nacrta Demokratske alternative iz 1963. godine, Nacrt za Demokratsku alternativu iz 1982. pretrpio je bitne promjene, u osnovi proizašle kao rezultat djelatnosti Zulfikarpašića i istomišljenika. U odnosu na prethodna stajališta uvedena su dva nova principa. Sada je prihvaćeno načelo da su Bošnjaci jedan od ravnopravnih i posebnih naroda buduće državne zajednice, koju sada čini šest naroda za razliku od koncepta sa četiri naroda iz 1963. godine, a Skoplju i Sarajevu priznaje se status ravnopravnih nacionalnih i političkih centara sa Zagrebom, Beogradom i Ljubljanom. Kao drugi princip, a na zalaganje bošnjačkog dijela Alternative, prihvaćen je princip nepromjenjivosti granica postojećih socijalističkih republika, osim u slučajevima plebiscitarnog pristanka većine stanovništva sporne teritorije. ${ }^{2}$

Za njega je devedesetih godina prošlog stoljeća pitanje bilo: kako očuvati Bosnu i Bošnjake i dobiti mir? U emigraciji su se pripremali i razmatrali različiti koncepti kraja Jugoslavije, najrjeđe njene transformacije, i bošnjačka emigracija bila je dio tih narativa.

Već 1963. on jasno ističe da su borba za samostalnost Bosne i ravnopravnost Bošnjaka osnovne odlike bošnjačke politike. Bosna i Hercegovina je srž spora Srba i Hrvata i aktivna uloga Bošnjaka u razrješenju tog spora je po njemu od „prvorazrednog značaja”. Bošnjaci se, po njemu, u taj spor moraju aktivno uključiti i to ne na način da sa Srbima prave pakt protiv Hrvata niti sa Hrvatima protiv Srba, već na principima bratske saradnje i ravnopravnosti. On je zagovarao politiku ekvidistance prema Zagrebu i Beogradu, potpuno u duhu bosanske političke tradicije.

Treće, Zulfikarpašić je bio najistaknutija figura bošnjačke emigracije. Osnivanjem časopisa Bosanski pogledi 1955. godine kreirao je platformu za bošnjačko i bosansko političko, nacionalno i kulturno djelovanje u tada brojnoj i vrlo politički aktivnoj protukomunističkoj jugoslavenskoj emigraciji, koja je shodno svome ideološkom i ratnom naslijeđu bila nesklona, da ne kažemo neprijateljska prema samostalnosti Bosne i političkom subjektivitetu bošnjačkog naroda. Zulfikarpašić je, s Teufikom Velagićem i Smailom Balićem prije svega, prvi hrabro i kompetentno u emigraciji pristupio promoviranju i branjenju bošnjačkih i bosanskih interesa. 
Istovremeno, treba imati na umu da su u dijelovima emigracije u različitim vremenima prilično različite grupe osnivale svoja udruženja sa dosta bombastičnim i zahtjevnim naslovima. U načelu, svaka je grupa, a živjelo se i djelovalo po grupama u političkom i u geografskom smislu jer su Bošnjaci bili rasuti širom svijeta, sebe smatrala predstavnikom cijelog bošnjačkog naroda i nastojala da svoju nacionalno-političku koncepciju proturi, nametne ili proglasi jedino važećom i za cijeli narod spasonosnom. Pored bošnjačke nacionalno-političke usmjerenosti, posebno su bile aktivne i brojne prohrvatske i prosrpske/projugoslavenske orijentacije unutar bošnjačke emigracije.

Najveća i najorganiziranija skupina Bošnjaka koja se pedesetih godina opredjeljivala u hrvatskom nacionalno-političkom smislu bila je nastanjena u Velikoj Britaniji. Bila je okupljena oko Društva bosanskohercegovačkih i sandžačkih Hrvata muslimana, koje je izdavalo glasilo Svijest i službeni glasnik udruženja Islam. To udruženje je povodom petogodišnjice rada izdalo i vlastitu Spomenicu. ${ }^{3}$ Ova grupacija bošnjačkih emigranata najvećim dijelom je nastala od ostataka Handžar divizije, koje su Englezi iz dijelova Austrije i Njemačke odveli na rad u Veliku Britaniju, a u političkom smislu bila je na programu hrvatske demokratske emigracije okupljene oko HSS-a. Njen najistaknutiji intelektualni predvodnik bio je Hazim Šatrić, dok je u organizacijskom smislu prva ličnost bio Mujo Čolan.

Zbog četničkih zločina nad Bošnjacima u Drugom svjetskom ratu prosrpska nacionalno-politička usmjerenost među bošnjačkim emigrantima bila je duboko kompromitirana, tako da su se takva i slična stajališta u osnovi propagirala pod maskom različitih jugoslavenskih ideologija. Kao nacionalno deklarirani Srbi unutar bošnjačke emigracije pedesetih godina se izdvajaju Bećir Đonlagić i Omer Kajmaković, a programski su bili za monarhističku Jugoslaviju i borbu protiv komunizma, dok se s jugoslavenskim stajalištima izdvajao Šemso Dervišević.

Zulfikarpašić je spajao antifašističke vrijednosti i liberalno naslijeđe Evrope, čvrsto je zagovarao pravo na izbor, demokratsku, izbornu, pluralnu višepartijsku legitimaciju vlasti. Antifašizam i liberalizam bile su njegove diferentie specifice u odnosu na ostale orijentacije unutar bošnjačke emigracije, prije svega prosrpsku, prohrvatsku i projugoslavensku, koje su ostale povijesno nerelevantne budući da su bile samo refleksi ili ostaci poraženih ideologija i pokreta u Drugom svjetskom ratu.

„Spomenica bosanskoherc. i sandžačkih Hrvata muslimana”, Hrvatski glas, 9. svibnja/maja 1955. 
Svoj liberalni aktivizam Zulfikarpašić je institucionalizirao osnivanjem Liberalnog saveza Bošnjaka, koji je kao ravnopravni sudionik Liberalne internacionale bio i forma priznavanja nacionalne posebnosti Bošnjaka u godinama kada još takve politike u matičnoj zemlji nije bilo. Naime, sva demokratski usmjerena jugoslavenska emigracija politički je prihvatila teoriju liberalizma. Već od 1957. godine predstavnici Hrvata, Slovenaca i Bošnjaka odlučuju da se uspostavi Savez liberalnih izbjeglica iz Jugoslavije, u koji mogu ući kao predstavnici suverenih naroda, organiziranih u vlastite grupe: Srbi, Slovenci, Hrvati, Makedonci i Muslimani iz Bosne i Hercegovine. Te grupe su kroz Savez postali članovi Komiteta liberala u egzilu (Committee of Liberal Exiles - CLE) i Liberalne internacionale. U izradi statuta pošlo se od principa samoopredjeljenja naroda i prava svakog naroda na zasebnu državu. Liberalna internacionala, udruženje evropskih liberalnih stranaka, jedina je značajna međunarodna politička asocijacija tih godina koja je primala stranke i grupe u egzilu kao ravnopravne članove. Predstavnik bošnjačke liberalne grupe Adil Zulfikarpašić od 1960. godine je kontinentalni tajnik CLE-a i član njegovog Izvršnog komiteta. U tom svojstvu bio je zadužen kao veza između liberalnih grupa i CLE-a i liberalnih stranaka u Evropi te pojedinih nacionalnih grupa u egzilu. Djelatnošću bošnjačkih liberala došlo je do toga da sve južnoslavenske nacionalne grupe budu samostalno prisutne i predstavljene u Liberalnoj internacionali. ${ }^{4}$

Principi liberalizma i antifašizma nisu bili opredjeljujući u godinama raspada socijalističke Jugoslavije, tako da Zulfikarpašićevo političko djelovanje nakon povratka u zemlju i aktivnog uključenja u njen politički život nije naišlo na plodno tlo. Pokušaj demokratske i mirne transformacije Jugoslavije nisu podržale novostasajuće nacionalne/republičke elite, što je za posljedicu imalo dugotrajne i krvave ratove. 


\section{Political Life of the Bosnian Anti-Communist Emigration}

\begin{abstract}
Adil Zulfikarpasic is the most important figure in the Bosnian anti-communist emigration. He dedicated his emigrant political life to the democratization and liberalization of his native country, in accordance with the highest principles of humanism and freedom. On these principles, he actively participated in
\end{abstract}

all institutional forms of gathering of Yugoslav emigrants in the West. Liberalism and anti-fascism are the basic ideological guidelines of his political engagement.

KEYWORDS: anti-fascism, liberalism, Bosniakism, Bosnia, democracy. 